\title{
JOB DISSATISFACTION AS A POSSIBLE RISK FACTOR IN CORONARY HEART DISEASE*
}

\author{
Stephen M. Sales, Ph.D. \\ Carnegie-Mellon University, Michigan, U.S.A. \\ and \\ JAmes House, Ph.C. \\ University of Michigan, Michigan, U.S.A.
}

(Received 18 March 1970; in revised form 31 August 1970)

IN RECENT years, various investigations have attempted to elucidate the relationship between social status and risk of death due to coronary heart disease. In general, the data presented in these studies have shown no consistent pattern. In some investigations [1-6] a positive relationship has been reported between status and coronary disease. In other studies [7-10] a negative relationship has been noted between these variables. In still other investigations a curvilinear relationship--either U-shaped [11-13] or inverted-U-shaped [14] — has been observed. In further studies [15-17] a lack of any appreciable relationship has been reported. This variety of results has surely contributed to the general impression held by writers of review articles [18-19] that social status and coronary disease are essentially unrelated in the population at large.

The present authors, like many others, believe that the social environment can exert an important influence upon an individual's risk of coronary disease. However, we do not feel that social status per se plays this role. Rather, we believe that social factors which may be associated with status exert such influence. In an earlier paper [20], the senior author suggested that particular forms of social stress may contribute to heightened risk of coronary disease. In the present report, we shall attempt to demonstrate that an individual's dissatisfaction with his job has similar etiologic implications.

We shall describe here three separate investigations designed to test this general hypothesis. Each of these studies involves a different set of subjects and slightly different methods; however, the general procedure is similar from study to study. In each investigation, we select various occupational groups for whom (a) mortality ratios due to coronary heart disease and (b) average levels of job satisfaction are known. We then relate these two variables to each other. The design of these studies

\footnotetext{
*The authors are indebted to Margaret Child, Sidney Cobb, Frederick H. Epstein, John R. P. French, Jr., and Esther Sales for their careful reading of an earlier version of this paper. We also are particularly grateful to Patricia Cain Smith and Jules Scheffers for making available the data employed in the third study reported here, and to Wynn Winkler for statistical assistance. Preparation of this manuscript was facilitated by a grant (\#NGR-23-005-185) from the National Aeronautics and Space Administration.
} 
is thus similar to that used in most 'ecological' epidemiologic investigations, although the putative causal factor studied here (job dissatisfaction) is hardly a conventional epidemiologic variable.

\section{STUDY I}

\section{Methods}

The first study reported here involves data on 16 different occupational groups; the groups used are shown in the first column of Table 1. The overall level of job satisfaction within each of these groups has been estimated from the per cent of individuals within each group who respond "yes" to questionnaire items such as, "If you had your life to live over, would you like to wind up in the same line of work as the one you're doing now?" and (for scholars), "If you had it to do over again, would you choose the same line of study?" These job satisfaction data have not been collected by the present authors; rather, the figures involved represent the end products of 3 previously-published investigations [21-23].

Table 1. Occupational groups used in Study I

\begin{tabular}{|c|c|}
\hline $\begin{array}{l}\text { Groups for whom job satisfaction } \\
\text { data are available }\end{array}$ & Apparently equivalent census groups \\
\hline \multicolumn{2}{|l|}{ Blue collar } \\
\hline Farmers & Farmers and farm laborers \\
\hline Skilled printers & Printing craftsmen, except compositors and typesetters \\
\hline Skilled steelworkers & $\begin{array}{l}\text { Operatives and kindred workers, not elsewhere classified } \\
\text { (n.e.c.), primary metal industries }\end{array}$ \\
\hline Textile workers & Laborers (n.e.c.), textile mill products and apparel \\
\hline Unskilled steelworkers & Laborers (n.e.c.), primary metal industries \\
\hline Unskilled automobile workers & Laborers (n.e.c.) transportation equipment \\
\hline Skilled automobile workers & Operatives and kindred workers (n.e.c.), motor vehicles \\
\hline Paper workers & $\begin{array}{l}\text { Operatives and kindred workers (n.e.c.), paper and allied } \\
\text { products }\end{array}$ \\
\hline \multicolumn{2}{|l|}{ White collar } \\
\hline Urban university professors & College presidents, professors, and instructors (n.e.c.) \\
\hline Biologists & Natural scientists (n.e.c.) \\
\hline Physicists & Natural scientists (n.e.c.) \\
\hline Chemists & Chemists \\
\hline Lawyers, firm and solo & Lawyers and judges \\
\hline Managers & Managers, officials and proprietors, except farm \\
\hline Sales & Sales workers \\
\hline Clerical & Clerical and kindred workers \\
\hline
\end{tabular}

The first of these studies was performed in the late 1940's by the Roper organization. It involved (a) random samples of 3 scientific groups (biologists, chemists, and physicists), with an overall $N$ of 4000 , and (h) a nation-wide sample of 3000 workingclass males. The data reported here have been taken from Blauner's [21] secondary analysis of these data. Unfortunately, Blauner failed to report the number of subjects in each of the 11 groups ( 3 scientific, 8 working-class) which he analyzed. IIowever, considering the overall size of the sample, one may reasonably assume these $N$ 's to be acceptably large. 
The second study [22] involved probability samples of lawyers and university professors in the Detroit area during the 1950's. This study surveyed 207 lawyers and 68 professors. The third study [23], also performed in the 1950's, used a national cross-section of working men including 127 managers or proprietors, 55 sales workers, and 46 clerical employees.

For each of the occupational groups in these 3 studies, an apparently equivalent census classification was chosen. These apparently equivalent census groups are shown in the second column of Table 1 . The standardized mortality ratio (SMR)* of men aged $25-59 \mathrm{yr}$ in these groups due to arteriosclerotic heart disease, including coronary disease (rubric 420) in 1950 has been published by the Department of Health, Education, and Welfare [24]. These mortality ratios constitute the measure of coronary disease used in this study. Finally, because of the interest which has traditionally been attached to this variable, a measure of each group's socioeconomic status was established. The status measure employed was the Duncan socioeconomic index [25], an index which is widely used in sociolo zic research. The data used in Study I are presented in Table 2.

Table 2. Data Used in Study I

\begin{tabular}{|c|c|c|c|}
\hline Occupational group & $\begin{array}{l}\text { Per cent } \\
\text { satisfied }\end{array}$ & $\begin{array}{c}\text { Coronary disease } \\
\text { SMR }\end{array}$ & Status \\
\hline Farmers* & 84 & 66 & 14 \\
\hline Skilled printers* & 52 & 110 & 49 \\
\hline Skilled steelworkers* & 41 & 85 & 15 \\
\hline Textile workers* & 31 & 120 & 03 \\
\hline Unskilled steelworkers* & 21 & 125 & 04 \\
\hline Unskilled automobile workers* & 16 & 176 & 13 \\
\hline Skilled automobile workers* & 41 & 68 & 21 \\
\hline Paper workers* & 42 & 73 & 19 \\
\hline University professors $\dagger$ & 93 & 71 & 84 \\
\hline Biologists* & 89 & 69 & 80 \\
\hline Physicists* & 89 & 69 & 80 \\
\hline Chemists* & 86 & 100 & 79 \\
\hline Lawyers $\nmid$ & 80 & 124 & 93 \\
\hline Managers & 69 & 116 & 79 \\
\hline Salest & 52 & 126 & 50 \\
\hline Clerical + & 42 & 103 & 44 \\
\hline
\end{tabular}

* Data provided by Blauner [21].

† Data provided by Wilensky [22].

$\ddagger$ Data provided by Gurin, Veroff and Feld [23].

Product-moment correlations are the primary statistical tool used in Study I. These correlations are calculated separately within the blue-collar and white-collar classifications, since earlier research [reviewed in 21, 23, and 26] has shown these broad groups to be non-comparable with regard to job satisfaction.

*The SMR is defined [24] as the tabulated deaths for an occupation-cause group divided by the expected deaths for this occupation-cause group and multiplied by 100 . The SMR is standardized for age. 


\section{Findings}

In the present data, there is no particular indication that social status is related to coronary disease mortality. The correlation between status (as measured by the Duncan index) and the SMR for coronary disease is $-\mathbf{0 . 2 8 8}$ for the white-collar groups and -0.170 for the blue-collar groups. Neither of these correlations is statistically significant. In addition, the white-collar groups do not differ from the blue-collar groups in their average mortality ratios. The mean SMR for the whitecollar groups is 97 and that for the blue-collar groups is 103.

On the other hand, the data indicate a strong relationship between job satisfaction and coronary disease. For the white-collar groups, a correlation of $-0.630, p<0.05^{*}$, was observed between job satisfaction and coronary disease. The parallel correlation for the blue-collar groups was $-0.716, p<0.05$. These correlations are reasonably large and are congruent with the hypothesis which guides this investigation; as expected, high levels of job satisfaction do tend to be associated with low rates of death from coronary disease.

However, this conclusion is somewhat clouded by the presence of large positive correlations between social status and job satisfaction in both blue- and white-collar groups. For the 8 white-collar groups, this relationship was found to be 0.881 , $p<0.001$; for the 8 blue-collar groups, the same correlation was found to be 0.344 (not significant). These correlations are congruent with previous findings [reviewed in 27], and they raise an important question regarding the unique variance, if any, which is contributed by job satisfaction per se to a group's death rate from coronary disease. In an attempt to answer this question, partial correlations were computed between coronary disease death rates and job satisfaction, with the effects of social status held constant by means of the statistical procedure. These partial correlations were found to be -0.830 for the white-collar groups and -0.744 for the blue-collar groups; both are significant beyond the 0.05 level. These data suggest that, regardless of a group's social status, its average level of job satisfaction will be strongly (and negatively) related to its rate of coronary disease.

\section{Discussion}

It should be clear that Study I involves a number of important methodologic ambiguities. The independent variable used here is measured by a single question, and single-question measures are highly unreliable [28]. Further, and perhaps more important, the specific question used differed slightly from occupational group to occupational group. In addition, the subject samples for the 16 groups used here are sometimes not random national samples of the groups involved, and the groups themselves are certainly not random representatives of occupational groupings in the United States. Finally, there is no guarantee that the occupational groups for whom job satisfaction data are available (e.g. skilled steelworkers) fully correspond to the census classifications (e.g. operatives and kindred workers, not elsewhere classified, primary metal industries) on which the coronary disease mortality data are based. Nevertheless, and with these problems taken into consideration, the data presented here do seem to indicate that job satisfaction is negatively related to coronary disease mortality.

\footnotetext{
*Since the direction of all correlations reported in this paper has been predicted in advance, onetailed significance tests have been employed throughout.
} 


\section{STUDY II}

Study II attempts to avoid some of the methodologic ambiguities which were present in Study I. This second study employs as a measure of job satisfaction not only a single question, but also a set of questions involving 6 different aspects of job satisfaction. These questions were asked in an identical form to subjects in all of the groups used here, so there is no possibility that error due to variations in question wording could have influenced the data. Finally, the data are based on a set of occupational groups which differs substantially from the set used in Study I. Of the 12 groups for which these new job satisfaction data are available, only 3 appeared in the previous investigation. This last consideration permits us not only to confirm, but also to extend the generality of the findings drawn from Study I.

\section{Methods}

Study II involves data gathered from a national sample of nonagriculturally employed men and from a similar sample of man in the Jackson, Michigan area [29]. These data were collected during the mid-1960's, and they provide usable information for 12 occupational groups. The groups used in Study II are listed in the first column of Table 3; all of these involve white-collar jobs.

TABLE 3. Occupational groups USED IN StUdy II

Groups for whom job satisfaction
data are available

Professors, librarians

Advising professions

School teachers

Scientists, physicians

Accountants, auditors

Engineers

Technicians

Managerial (salaried and selfemployed combined)

Bookkeepers

Other clerical

Sales (goods, services, and sales clerks combined)

Other sales
College presidents, professors, and instructors (not elsewhere classified)

Social, welfare, and recreation workers

Teachers (n.e.c.)

Physicians and surgeons

Accountants and auditors

Other technical engineers

Other professional, technical, and kindred workers

Managers, officials, and proprietors, except farm

\section{Bookkeepers}

Other clerical and kindred workers

Sales workers

Other specified sales workers

The average job satisfaction for each of these groups in terms of (a) an overall measure of satisfaction and (b) specific indices of intrinsic and extrinsic satisfaction have been reported by Robinson [29]. The overall measure was the per cent of individuals within each group who responded 'no' to the single question, 'Do you ever think of changing to another job or another type of work?" Intrinsic satisfaction was measured by the average of the respondents' satisfaction with their 'chance to use your skills or abilities' and their 'chance to learn or try out new things', while extrinsic satisfaction was measured by the subjects' satisfaction with their pay, job security, kind of work place, and co-workers. Four-point scales, from "very good" to "poor", were employed for the intrinsic and extrinsic satisfaction items. 
For each of the 12 occupational groups used here, an apparently equivalent census classification was chosen. These apparently equivalent groups are shown in the second column of Table 3. As in Study I, the standard mortality ratios in 1950 of men aged 25-59 in each of these groups for rubric 420 has been taken from the tables published by the Department of Health, Education, and Welfare [24]. Further, as in Study I, the Duncan socioeconomic index [25] for each of these groups has previously been established. The data used in Study II, and the $N$ 's involved in each of the 12 occupational samples, are presented in Table 4.

Table 4. Data used in Study II

\begin{tabular}{lrccccc}
\hline \multicolumn{1}{c}{$\begin{array}{c}\text { Occupational } \\
\text { group }\end{array}$} & $N$ & $\begin{array}{c}\text { Per cent } \\
\text { satisficd }\end{array}$ & $\begin{array}{c}\bar{X} \text { Intrinsic } \\
\text { satisfaction }\end{array}$ & $\begin{array}{c}\bar{X} \text { Extrinsic } \\
\text { satisfaction }\end{array}$ & $\begin{array}{c}\text { Coronary } \\
\text { disease } \\
\text { SMR }\end{array}$ & Status \\
\hline Professors, librarians & 8 & 75 & 1.44 & 1.80 & 71 & 84 \\
Advising professions & 36 & 69 & 1.32 & 1.67 & 79 & 66 \\
School teachers & 54 & 74 & 1.32 & 1.98 & 75 & 72 \\
Scientists, physicians & 16 & 62 & 1.56 & 1.64 & 131 & 92 \\
Accountants, auditors & 13 & 46 & 1.66 & 1.84 & 133 & 78 \\
Engineers & 43 & 44 & 1.76 & 1.74 & 89 & 87 \\
Technicians & 33 & 39 & 1.94 & 2.15 & 119 & 62 \\
Managerial & 131 & 65 & 1.67 & 1.81 & 116 & 62 \\
Bookkeepers & 18 & 78 & 1.81 & 2.21 & 103 & 51 \\
Other clerical & 150 & 58 & 2.62 & 2.02 & 105 & 44 \\
Sales & 50 & 38 & 2.02 & 2.13 & 126 & 50 \\
Other sales workers & 7 & 58 & 2.22 & 2.38 & 136 & 50 \\
\hline
\end{tabular}

Note - The data for intrinsic and extrinsic satisfaction are coded such that a low score implies high satisfaction. All data are provided by Robinson [29].

\section{Findings}

As in Study I, Study II revealed no particular relationship between social status and coronary disease. The correlation in question was -0.245 , not significant.

However, a significant negative correlation $(r=-0.547, p<0.05)$ was observed between the groups' total job satisfaction (as measured by the 'Do you ever think of changing to another job' question) and their rates of coronary heart disease. This finding is a substantial replication of the major finding reported in Study I, and it is clearly in line with the hypothesis which informs this report. Unlike Study I, however, the meaning of this relationship is not clouded by a strong correlation between status and overall job satisfaction; in the current investigation, this correlation was found to be only 0.050 (not significant).

In addition, the data from Study II suggest that the relationship between job satisfaction and coronary disease may be slightly stronger for intrinsic satisfactions than for extrinsic satisfactions. The correlation between the index of intrinsic satisfaction and the groups' mortality ratios from coronary disease is $-0.488(p<0.10)$, while the parallel correlation between the index of extrinsic satisfaction and rate of death from coronary disease is less $(-0.355)$ and not significant. These findings are not markedly altered by the statistical removal of the effects of social status from the correlations involved. The partial correlation between intrinsic job satisfaction and coronary disease (with social status removed from the relationship) is -0.454 
$(p<0.10)$; the parallel partial correlation between extrinsic job satisfaction and coronary disease is -0.268 (not significant). However, the difference between intrinsic satisfaction and extrinsic satisfaction as correlates of coronary disease is not statistically reliable. Further, the two forms of satisfaction correlate quite highly with each other $(r=0.609, p<0.05)$, so it is reasonable that they should exhibit similar relationships with other variables.

\section{Discussion}

In general, the findings from Study II appear to support those obtained in Study I. In both investigations, large significant negative correlations were observed between indices of job satisfaction and the coronary disease mortality ratios of the groups involved. The fact that Study II corroborates Study I in spite of differences between the two studies in (a) occupational groups used, (b) sample studied, and (c) job satisfaction measures employed adds substantial strength to this conclusion.

\section{STUDY III}

A major methodologic problem of Studies I and II has been the fact that the groups for which job satisfaction data are available are only apparently equivalent to the groups for which coronary disease rates have been established. There is no reason why these original data, having been collected for other purposes, should have been made compatible with the census categories. However, from the point of view of the present investigation, it would be preferable to base our conclusions on strictly comparable occupational categories. Study III is directed toward this goal.

For Study III, we have utilized one of the largest files of job satisfaction data currently available in the United States. These data, collected during the early 1960's by P. C. Smith and her associates, have been gathered from employees in 21 different organizations. These represent an extremely broad range of environments. Within each of these 21 organizations, a stratified sample of approximately 100 employees was selected. Each of these subjects responded to a 'job description' questionnaire (e.g. 'My job is boring') designed to measure 5 varieties of satisfaction (one of them intrinsic and four of them extrinsic). Dr. Smith has generously allowed us to use these data as the basis of Study III.

For the purposes of this study, we coded the occupational title of each of the original subjects in Smith's investigation into the census categories. This establishes absolute comparibility between the classifications on which job satisfaction data are available and those for which coronary disease death rates are known. We then computed average total satisfaction and also average intrinsic and extrinsic satisfaction (a) for all white-collar groups involving 8 or more subjects and (b) for all blue-collar groups involving 20 or more subjects. (As one would expect, the sample included far more blue-collar than white-collar employees, and the selection rules are an attempt to provide the largest possible number of blue- and white-collar occupational categories for which a reasonably stable estimate of job satisfaction is available.) This procedure yielded a total of 13 white-collar and 23 blue-collar groups. These groups, identified according to the census categories used, are presented in Table 5. Only 6 of the 36 groups involved have appeared in either Study I or Study II.

As in Studies I and II, the present investigation also employs these groups' SMR's from coronary disease and their socioeconomic statuses (as established on the Duncan 
index) in the analysis. The raw data used in this investigation, and the number of subjects in each of the 36 groups involved, are presented in Table 6 and 7.

\section{Findings}

The present data, like those available in Studies I and II, show no pronounced relationship between social status and coronary disease. For white-collar groups the correlation between these variables is -0.427 ; for blue-collar groups the parallel correlation is -0.119 . Neither of these correlations is statistically significant. In addition, there is no particular difference between the average SMR of the whitecollar groups and that of the blue-collar groups. The average SMR within the whitecollar category is 107 while the parallel figure within the blue-collar category is 100 .

Table 5. Occupational groups USed In Study III

\begin{tabular}{|c|c|}
\hline White-collar groups & Blue-collar groups \\
\hline Accountants and auditors & Electricians \\
\hline Chemists & Foremen (n.e.c.), manufacturing, durable goods \\
\hline Draftsmen and designers & Foremen (n.e.c.), manufacturing, non-durable goods \\
\hline Electrical engineers & Foremen (n.e.c.), nonmanufacturing industries \\
\hline $\begin{array}{l}\text { Engineers, not elsewhere classified } \\
\text { (n.e.c.) }\end{array}$ & Machinists and job setters \\
\hline Natural scientists & Molders, metal \\
\hline $\begin{array}{l}\text { Other professional, technical and } \\
\text { kindred workers }\end{array}$ & Toolmakers, and die makers and setters \\
\hline $\begin{array}{l}\text { Managers, officials and proprietors } \\
\text { (n.e.c.) manufacturing }\end{array}$ & Other craftsmen and kindred workers \\
\hline $\begin{array}{l}\text { Managers, officials, and proprietors } \\
\text { (n.e.c.), wholesale and retail trade }\end{array}$ & Filers, grinders and polishers, metal \\
\hline $\begin{array}{l}\text { Managers, officials, and proprietors } \\
\text { (n.e.c.), other industries }\end{array}$ & Truck drivers and deliverymen \\
\hline Bookkeepers & Welders and flame-cutters \\
\hline Other clerical and kindred workers & $\begin{array}{l}\text { Operatives and kindred workers (n.e.c.), stone, clay, and glass } \\
\text { products }\end{array}$ \\
\hline $\begin{array}{l}\text { Salesmen and sales clerks (n.e.c.), } \\
\text { retail trade }\end{array}$ & $\begin{array}{l}\text { Operatives and kindred workers (n.e.c.), fabricated metal } \\
\text { industries } \\
\text { Operatives and kindred workers (n.e.c.), machinery, except } \\
\text { electrical } \\
\text { Operatives and kindred workers (n.e.c.), electrical machinery, } \\
\text { equipment and supplies } \\
\text { Operatives and kindred workers (n.e.c.), transportation equip- } \\
\text { ment, except motor vehicle } \\
\text { Operatives and kindred workers (n.e.c.), other durable goods } \\
\text { Operatives and kindred workers (n.e.c.), yarn, thread, and } \\
\text { fabric mills } \\
\text { Operatives and kindred workers (n.e.c.), chemicals and allied } \\
\text { products } \\
\text { Other specified operatives and kindred workers } \\
\text { Janitors and porters } \\
\text { Laborers (n.e.c.), machinery, inciuding electrical } \\
\text { Laborers (n.e.c.), other non-durable goods }\end{array}$ \\
\hline
\end{tabular}

However, quite large negative correlations were observed for the white-collar groups between coronary disease and total satisfaction $(r=-0.635, p<0.01)$, intrinsic satisfaction $(r=-0.677, p<0.005)$, and extrinsic satisfaction $(r=-0.624, p<0.01)$. The 
statistical removal of the effects of social status does not materially alter these relationships. The partial correlations between job satisfaction and coronary disease mortality are -0.528 (total satisfaction), -0.591 (intrinsic satisfaction), and -0.512 (extrinsic satisfaction). All are significant beyond the 0.05 level.

Table 6. Data used in Study III, white-collar groups

\begin{tabular}{|c|c|c|c|c|c|c|}
\hline $\begin{array}{l}\text { Occupational } \\
\text { group }\end{array}$ & $N$ & $\begin{array}{c}\bar{X} \text { Total } \\
\text { satisfaction }\end{array}$ & $\begin{array}{l}\bar{X} \text { Intrinsic } \\
\text { satisfaction }\end{array}$ & $\begin{array}{l}\bar{X} \text { Extrinsic } \\
\text { satisfaction }\end{array}$ & $\begin{array}{l}\text { Coronary } \\
\text { disease } \\
\text { SMR }\end{array}$ & Status \\
\hline Accountants, auditors & 22 & 30.03 & 38.05 & 28.02 & 133 & 78 \\
\hline Chemists & 23 & 33.90 & 41.35 & 32.04 & 100 & 79 \\
\hline Designers, draftsmen & 22 & 31.89 & 41.00 & 29.61 & 114 & 70 \\
\hline Electrical engineers & 8 & 36.02 & 44.62 & 34.62 & 83 & 84 \\
\hline Other engineers & 96 & 33.16 & 42.44 & 30.84 & 89 & 87 \\
\hline Natural scientists & 9 & 35.55 & 43.44 & 33.58 & 69 & 80 \\
\hline $\begin{array}{l}\text { Other professional } \\
\text { workers }\end{array}$ & 61 & 33.99 & 40.80 & 32.29 & 119 & 65 \\
\hline Managers, manufacturing & 98 & 35.53 & 43.11 & 33.64 & 111 & 79 \\
\hline $\begin{array}{l}\text { Managers, wholesale and } \\
\text { retail }\end{array}$ & 15 & 33.15 & 41.33 & 31.11 & 126 & 70 \\
\hline Managers, other & 49 & 35.21 & 42.83 & 33.30 & 105 & 62 \\
\hline Bookkeepers & 12 & 33.53 & 42.92 & 31.18 & 103 & 51 \\
\hline Other clerical workers & 359 & 30.00 & 37.83 & 28.04 & 105 & 44 \\
\hline Salesmen and sales clerks & 25 & 29.71 & 39.24 & 27.33 & 130 & 39 \\
\hline
\end{tabular}

It may be noted that, as in Study II, intrinsic satisfactions show a slightly higher correlation with coronary disease mortality than is shown by extrinsic satisfactions. However, also as in Study II, the difference between these correlations is not statistically reliable. This lack of a reliable difference seems quite reasonable, since the two forms of satisfaction are extremely highly related to each other in this sample of groups $(r=0.864, p<0.001)$.

This pattern is repeated, although not significantly, for the blue-collar groups. The relationship between total satisfaction and coronary disease in these groups is -0.137 ; the relationship between coronary disease and intrinsic satisfaction is -0.220 , and the relationship between coronary disease and extrinsic satisfaction is -0.087 . None of these correlations is significantly different from zero, although all of them are in the predicted direction.

\section{Discussion}

The findings derived from the white-collar groups seem to be acceptable replications of the data reported in Studies I and II. The failure of these relationships to be significantly repeated for the sample of blue-collar groups is surprising. One can speculate that this failure to replicate is due to some peculiarity in the sample of organizations chosen by the Smith group, or to the invalidity of the questionnaire involved for measuring satisfaction in blue-collar workers. These speculations are perhaps supported by the fact that, in the present data, blue-collar laborers (who have particularly high rates of coronary disease) show essentially the same degrees of job satisfaction as is shown by blue-collar operatives (who have particularly low rates of coronary disease). This is a most unusual result; other investigations [summarized in 
21-23 and 26-27] have almost invariably found operatives to have substantially greater satisfaction than laborers. In any event, however, the pattern of data derived from this sample of blue-collar groups does parallel that reported in the previous studies.

Table 7. Data used un Study III, Blue-collat groups

\begin{tabular}{|c|c|c|c|c|c|c|}
\hline $\begin{array}{l}\text { Occupational } \\
\text { group }\end{array}$ & $N$ & $\begin{array}{c}\bar{X} \text { Total } \\
\text { satisfaction }\end{array}$ & $\begin{array}{r}\bar{X} \text { Intrinsic } \\
\text { satisfaction }\end{array}$ & $\begin{array}{l}\bar{X} \text { Extrinsic } \\
\text { satisfaction }\end{array}$ & $\begin{array}{c}\text { Coronary } \\
\text { disease } \\
\text { SMR }\end{array}$ & Status \\
\hline Electricians & 21 & 28.61 & 31.10 & 27.99 & 127 & 44 \\
\hline $\begin{array}{l}\text { Foremen, manufacturing, } \\
\text { durable goods }\end{array}$ & 114 & 33.86 & 41.37 & 31.98 & 92 & 60 \\
\hline $\begin{array}{l}\text { Foremen, manufacturing, } \\
\text { non-durable goods }\end{array}$ & 40 & 34.72 & 42.90 & 32.68 & 99 & 46 \\
\hline $\begin{array}{l}\text { Foremen, non- } \\
\text { manufacturing }\end{array}$ & 22 & 34.34 & 43.14 & 32.14 & 90 & 44 \\
\hline $\begin{array}{l}\text { Machinists and job } \\
\text { setters }\end{array}$ & 77 & 29.02 & 29.17 & 28.98 & 143 & 33 \\
\hline Molders, metal & 20 & 32.50 & 32.81 & 32.42 & 96 & 12 \\
\hline Tool and die makers & 32 & 31.55 & 43.06 & 28.76 & 97 & 50 \\
\hline Other craftsmen & 192 & 29.89 & 35.45 & 28.50 & 101 & 32 \\
\hline Filers, grinders & 51 & 28.50 & 33.61 & 27.22 & 79 & 22 \\
\hline Truck drivers & 36 & 29.76 & 33.00 & 28.93 & 100 & 15 \\
\hline Welders and flamecutters & 46 & 27.08 & 29.38 & 26.51 & 102 & 24 \\
\hline $\begin{array}{l}\text { Operatives, stone and } \\
\text { glass }\end{array}$ & 29 & 28.41 & 30.33 & 27.93 & 89 & 23 \\
\hline $\begin{array}{l}\text { Operatives, fabricated } \\
\text { metal }\end{array}$ & 24 & 33.51 & 31.33 & 34.06 & 82 & 15 \\
\hline Operatives, machinery & 100 & 27.89 & 33.28 & 26.54 & 71 & 22 \\
\hline Operatives, elcctrical & 57 & 32.34 & 36.14 & 31.39 & 85 & 26 \\
\hline Operatives, transportation & 47 & 25.49 & 29.15 & 24.58 & 97 & 23 \\
\hline $\begin{array}{l}\text { Operatives, other } \\
\text { durables }\end{array}$ & 34 & 31.31 & 30.98 & 31.39 & 84 & 16 \\
\hline $\begin{array}{l}\text { Operatives, yarn and } \\
\text { fabric }\end{array}$ & 56 & 26.45 & 28.07 & 26.04 & 113 & 02 \\
\hline Operatives, chemicals & 31 & 29.28 & 33.10 & 28.32 & 59 & 20 \\
\hline Other specified operatives & 306 & 29.00 & 32.99 & 28.00 & 75 & 18 \\
\hline Janitors and porters & 25 & 29.33 & 30.14 & 29.13 & 83 & 09 \\
\hline Laborers, machinery & 40 & 28.26 & 32.17 & 30.36 & 169 & 10 \\
\hline $\begin{array}{l}\text { Laborers, other non- } \\
\text { durables }\end{array}$ & 22 & 30.72 & 30.68 & 27.66 & 176 & 08 \\
\hline
\end{tabular}

\section{OTHER DISEASES}

In an attempt to determine whether the findings reported above are specific to coronary disease, analyses parallel to those performed in Studies I, II, and III were also computed for other major causes of death. These rubrics, the only ones which are reported for many of the work groups studied here, are as follows: 001-019 (tuberculosis, all forms), 140-205 (malignant neoplasms, including neoplasms of lympathic and hematopoietic tissues), 260 (diabetes mellitus), 440-443 (hypertension with heart disease), 48-493 (influenza and pneumonia), and E800-E962 (accidents). In no case was the pattern reported above duplicated for any of these other causes of death. These findings are in accord with the hypothesis that the current results are specific to coronary disease and are not merely a function of overall mortality rates. 


\section{DISCUSSION}

The data presented here provide reasonably strong support for the hypothesis that job satisfaction is negatively related to a group's rate of death from coronary heart disease. In each of 3 studies, significant negative correlations between job satisfaction and coronary disease mortality have been found; this has remained true in spite of large differences between the studies in (a) groups investigated and (b) measures employed. To be sure, each of these studies has involved important methodologic problems. However, the influence of many of these is likely to be conservative.

Naturally, the data reported here are drawn from analysis of grouped or 'ecological' data. Because of this methodologic approach, one might be tempted to maintain that the present data are irrelevant in terms of individuals' risk of death from coronary heart disease. It is true, of course, that these findings are relevant to individual persons only in terms of an estimate of probability. However, data supportive of the general hypothesis investigated here have also been obtained using individuals as the sampling points. In this earlier study [20], individuals were asked to perform an experimental task for $1 \mathrm{~h}$. Their enjoyment of the experiment was negatively and significantly correlated with increases in their levels of serum cholesterol. Although the dependent variable used in this earlier study was not coronary disease mortality, the findings do nevertheless seem quite congruent with those presented here. In addition, this experimental result does not suffer from the limitations (e.g. non-random samples, self-selection of individuals into groups, possible spurious variables, indeterminant direction of causality) which characterize correlational studies such as those reported here. Of course, the present argument would be considerably strengthened by the discovery of a negative relationship between individuals' satisfaction with their organizational roles and their risk of death from coronary disease. Naturally, a prospcetive investigation would be ideal for testing this hypothesis.

As with other two-variable studies, the present investigations offer no assurance that the observed relationships are not due to correlations between the variables used here and some third, spurious factor. For instance, 'job stress' could cause both (a) high risk of death from coronary disease and (b) low levels of job satisfaction. This would lead to an observed correlation between satisfaction and coronary disease, even when no causal relationship between these variables existed. Such a pattern of correlations was observed in the previously-cited laboratory investigation [20]. Ilowever, the data available in that study indicated that the job stress in question could not account for the observed relationship between job satisfaction and changes in the subjects' levels of serum cholesterol. Similarly, age could account for the present findings if older workers tended to be less satisfied than younger workers. However, research [e.g. 31] appears to indicate that older workers, at least up to age 60 , are considerably more satisfied than younger workers. These considerations do not demonstrate that the relationship between coronary disease and job satisfaction could not be due to some third, spurious variable. However, they at least remove some of the morc obvious spurious variables from contention.

In a sense, the present hypothesis is not new to the medical literature. For instance. a recent paper [32] has indicated an etiologic relationship between status incongruence and risk of death from coronary disease; significantly, status incongruence clearly appears to be one factor which decreases individuals' job satisfaction [e.g. 33]. Furthermore, Wolf [e.g. 34] has long maintained that individuals who "strive without 
joy" are those who finally succumb to coronary disease. Wolf's argument has been largely based on clinical data, with all their potential biases. However the population data presented here fully support Wolf's argument. The present authors would not, like Wolf, speak of a 'Sisyphus complex' which haunts victims of coronary disease. After all, there is no evidence that Sisyphus himself ever exhibited any of its symptoms. However, we do believe that 'striving without joy' may indeed lead to an increased risk of coronary disease-and that 'striving with joy' may reduce this risk. Further, we are excited by the possibility that changing work environments so as to raise individuals' levels of job satisfaction may thereby lower these individuals' risk of coronary disease. This possibility represents one of the ways in which social psychology can contribute to practical programs of preventive medicine.

\section{REFERENCES}

1. Biorck G, Blomqvist G, Sievers J: Studies on myocardial infarction in Malmo, 1935-1954-II. Infarction rate by occupational group. Acta Med Scand 161:21, 1958

2. Breslow L, Buell P: Mortality from coronary heart disease and physical activity of work in California. J Chron Dis 11: 421, 1960

3. Registrar General of England and Wales: The Registrar General's Decennial Supplement, England and Wales, 1951, occupational mortality-II. Volume 1, Commentary, H.M.S.O., 1958

4. Syme SL, Borhani NO, Buechley RW: Cultural mobility and coronary heart disease in an urban area. Amer J Epidem 82: 334, 1966

5. Syme SL, Hyman MM, Enterline PE: Some social and cultural factors associated with the occurrence of coronary heart disease. J Chron Dis 17: 277, 1964

6. Wardwell WI, Hyman M, Bahnson CB: Stress and coronary heart disease in 3 field studies. J Chron Dis 17: 73, 1964

7. Bainton CR, Peterson DR: Deaths from coronary heart disease in persons $50 \mathrm{yr}$ of age and younger. New Eng J Med 268: 569, 1963

8. Hinkle LE, Jr, Whitney LH, Lehman EW et al: Occupation, education, and coronary heart disease. Science $161: 238,1968$

9. Kent AP, McCarroll JR, Schweitzer MD et al: A comparison of coronary artery disease (arteriosclerotic heart disease) deaths in health areas of Manhattan, New York City. Amer J Public Health 48: 200, 1958

10. McConough JR, Hames CG, Stulb SC et al: Coronary heart disease among Negroes and whites in Evans County, Georgia. J Chron Dis 18: 443, 1965

11. Lee RE, Schneider RF: Hypertension and arteriosclerosis in executive and non-executive personnel. JAMA 167: 1447, 1958

12. Pell S, D'Alonzo CA: A 3-yr study of myocardial infarction in a large employed population. JAMA 175: 139, 1961

13. Pell $S, D^{\prime}$ Alonzo CA: Acute myocardial infarction in a large industrial population. JAMA 185: 831,1963

14. Mortenson JM, Stevenson TT, Whitney LH: Mortality due to coronary disease analyzed by broad occupational groups. Arch Ind Health 19: 1, 1959

15. Berkson DM, Stamler J, Lundberg HA et al: Socioeconomic correlates of atherosclerotic and hypertensive heart diseases. Ann NY Acad Sci 84: 835, 1960

16. Lilienfeld AM: Variations in mortality from heart disease. Public Health Rep 71: 545, 1956

17. Guralnick L: Mortality by occupation level and cause of death among men 20-64 yr of age, United States, 1950. Vital Statistics Special Reports 53: 1963

18. Antonovsky A: Social class and the major cardiovascular diseases. J Chron Dis 21: 65, 1968

19. Lehman EW: Social class and coronary heart disease: A sociological assessment of the medical literature. J Chron Dis 20: 381, 1967

20. Sales SM: Organizational role as a risk factor in coronary disease. Admin Sci Quart 14: 325, 1969

21. Blauner $\mathbf{R}$ : Work satisfaction and industrial trends in modern society, in Galenson $\mathbf{W}$, Lipset SM: Labor and Trade Unionism. New York, John Wiley and Sons, 1960

22. Gurin G, Veroff J, Feld S: Americans View their Mental Health. New York, Basic Books, 1960

23. Wilensky HL: Varieties of work experience, in Barow H: Man in a World of Work. Boston, Houghton Mifflin, 1964 
24. Guralnick L: Mortality by occupation and cause of death among men 20-64 yr of age: United States, 1950. Vital Statistics Special Reports 53: 1963.

25. Reiss AJ, Jr, Duncan OD, Hatt P et al: Occupations and Social Status. New York, Free Press, 1961

26. Robinson JP, Athanasiou R, Head KB: Measures of Occupational Attitudes and Occupational Characteristics. Ann Arbor, Michigan, Institute for Social Research, 1969

27. Porter LW, Lawler EE, III: Properties of organizational structure in relation to job attitudes and job behavior. Psychol Bull 64: 23, 1965

28. McNemar Q: Psychological Statistics, 3rd ed. New York, John Wiley and Sons, 1962

29. Robinson J: Occupational norms and differences in job satisfaction: A summary of survey research evidence, in Robinson J, Athanasiou R, Head, KB: Measures of Occupational Attitudes and Occupational Characteristics. Ann Arbor, Michigan, Institute for Social Research, 1969, 25

30. Smith PC, Kendall LM, Hulin CL: The Measurement of Satisfaction in Work and Retirement. Chicago, Rand McNally and Company, 1969

31. Saleh SD, Itis JL: Age and level of job satisfaction. Personnel Psychol 17: 425, 1964

32. Shekelle RB, Ostfeld AM, Paul $O$ : Social status and incidence of coronary heart disease. J Chron Dis 22: 381, 1969

33. Adams $S$ : Status congruency as a variable in small group performance. Soc Forces $32: 16,1953$

34. Wolf S: Disease as a way of life. Perspect Biol Med 4:288, 1961 